\title{
Hubungan Metode Tanya Jawab dengan Minat Belajar Peserta Didik pada Mata Pelajaran Pendidikan Agama Islam
}

\author{
M. YUSUF AHMAD* \\ SYAHRAINI TAMBAK** \\ NIA CONSTANTIANI***
}

\author{
*Fakultas Agama Islam (FAI) Universitas Islam Riau (UIR) Pekanbaru \\ Jl. Kaharuddin Nasution, No. 113, Perhentian Marpoyan Pekanbaru 28284 \\ **Fakultas Agama Islam (FAI) Universitas Islam Riau (UIR) Pekanbaru \\ Jl. Kaharuddin Nasution, No. 113, Perhentian Marpoyan Pekanbaru 28284 \\ e-mail: syahraini_tambak@yahoo.co.id \\ ***Fakultas Agama Islam (FAI) Universitas Islam Riau (UIR) Pekanbaru \\ Jl. Kaharuddin Nasution, No. 113, Perhentian Marpoyan Pekanbaru 28284
}

\begin{abstract}
Abstrak: Pendidikan Agama Islam ialah sebagai upaya sadar dan terencana dalam menyiapkan peserta didik untuk mengenal, memahami, menghayati hingga mengimani, bertaqwa dan, berakhlaq mulia dalam mengamalkan ajaran agama Islam dari sumber utamanya kitab suci Al-Qur'an dan Hadist melalui kegiatan bimbingan, pengajaran, latihan, serta penggunaan pengalaman. Hubungan metode tanya jawab dengan minat belajar peserta didik ialah untuk mengembangkan kreatifitas berfikir peserta didik secara aktif dan sistematis serta mendapat respon lisan dari peserta didik sehingga dapat menumbuhkan minat belajar dan pengetahuan baru dalam proses pembelajaran dengan menggunakan metode tanya jawab ini akan menarik perhatian peserta didik dan suasana kelas menjadi aktif. Namun study pendahuluan yang penulis lakukan pada peserta didik kelas VIII SMP Negeri 3 Kuansing guru telah menggunakan metode tanya jawab namun peserta didik kurang merespon pertanyaan yang diberikan oleh guru. Perumusan masalah dalam penelitian ini adalah bagaimana hubungan metode tanya jawab dengan minat belajar peserta didik. Tujuan penelitian adalah untuk mengetahui hubungan yang signifikan antara metode tanya jawab dengan minat belajar peserta didik. Jenis penelitian korelasional, populasi dan sampel 59 orang, teknik pengumpulan data dengan angket dan dokumentasi, Perumusan Berdasarkan hasil pengolahan dan analisis data yang telah penulis lakukan, maka diperoleh kesimpulan bahwa terdapat hubungan signifikan metode tanya jawab dengan minat belajar peserta didik pada mata pelajaran pendidikan agama islam kelas VIII di SMP Negeri 3 Simpang Raya Kecamatan Singingi Hilir Kabupaten Kuansing. Hal ini dibuktikan dengan nilai signifikansi lebih kecil dari 0,05yaitu $0,000<0,05$, maka Ho ditolak dan tingkat hubungan metode tanya jawab dengan minat belajar peserta didik sebesar 0,738. Menurut interpretasi koefisien korelasi nilai 0,738 terletak pada interval 0,600,799 dengan kriteria tingkat hubungan kuat.
\end{abstract}

Kata kunci: metode tanya jawab, minat belajar, peserta didik, PAI 


\section{PENDAHULUAN}

Minat merupakan hal yang penting dalam pendidikan karena minat (interest) mengandung kecenderungan yang tinggi atau keinginan yang besar terhadap sesuatu. Menurut raber dalam rahmah minat disebabkan ketergantungannya terhadap berbagai faktor internal lainnya, seperti pemusatan perhatian, keingintahuan, motivasi, dan kebutuhan (Rahmah, 2013:45).

Minat adalah suatu rasa lebih suka dan rasa keterikatan pada suatu hal atau aktivitas, tanpa ada yang menyuruh. Minat pada dasarnya adalah penerimaan akan suatu hubungan antara diri sendiri dengan sesuatu di luar diri. Semakin kuat atau dekat hubungan tersebut, semakin besar minat. Suatu minat dapat di ekspresikan melalui suatu pernyataan yang menunujukkan bahwa siswa lebih menyukai suatu hal dari pada hal lainnya, dapat pula dimanifestasikan melalui partisipasi dalam suatu aktifitas, siswa yang memiliki minat terhadap subyek tertentu cenderung untuk memberikan perhatian yang lebih besar terhadap subyek tersebut (Slameto, 2010:180).

Minat belajar ini sangatlah penting bagi peserta didik karena dapat menumbuhkan semangat dalam belajar, apabila tidak ada minat belajar maka akan sulit untuk memahami materi pelajaran yang ada, apabila peserta didik memiliki minat yang tinggi dalam belajar dan apabila ia bisa memahami materi yang telah dijelaskan oleh guru maka itu akan memudahkan guru dalam mengajar.

Metode adalah cara yang dapat digunakan untuk melaksanakan strategi (Wina sanjaya, 2010:127). Metode berarti cara kerja yang bersistem untuk memudahkan pelaksanaan suatu kegiatan guna mencapai tujuan yang ditetapkan (Ramayulis, 2013:191).

Dalam proses mengajar banyak sekali metode-metode yang bisa digunakan oleh guru dalam mengajar diantaranya adalah: metode ceramah, metode diskusi, metode pemberian tugas (resitasi), metode demonstrasi, metode pemecahan masalah (problem solving method), akan tetapi penulis lebih tertarik dengan metode tanya jawab, karena metode tanya jawab sangatlah menarik dalam belajar dan bisa menumbuhkan semangat karena metode ini bisa membantu peserta didik dalam proses pembelajaran. Biasanya guru yang menggunakan metode tanya jawab ini selalu memberikan pertanyaan pada peserta didik dan guru juga mengambil nilai dari pertanyaan yang bisa dijawab oleh peseta didik tersebut.

Metode tanya jawab menurut Abuddin Nata dalam Syahraini Tambak adalah cara penyajian pelajaran dalam bentuk pertanyaan, yang dikemukakan oleh peserta didik (Syahraini Tambak, 2014:280). Metode tanya jawab ini sangat berguna dalam mengajarkan peserta didik. Karena metode ini membiasakan peserta didik untuk mengungkapkan apa-apa yang terlintas dalam pikirannya dengan ungkapan yang teratur dan sistematis berani mengemukakan pendapatnya tanpa ada rasa takut dan gemetaran, Sehingga menambah kecintaan mereka terhadap pelajaran serta membangkitkan keaktifan berpikir kritis mereka.

Dari pengertian di atas penulis dapat menyimpulkan bahwa metode tanya jawab adalah suatu cara mengajar seorang guru di mana adanya umpan balik antara guru dan peserta didik dalam pembelajaran dengan cara guru memberikan suatu pertanyaan dan pertanyaan tersebut di jawab oleh peserta didik yang telah di tunjuk untuk menjawab pertanyaan tersebut, begitu 
juga sebaliknya ini juga untuk memudahkan peserta didik apabila belum paham dengan materi tersebut maka bisa menanyakan pada guru.

Hubungan metode tanya jawab dengan minat belajar peserta didik ialah untuk mengembangkan kreatifitas berfikir peserta didik secara aktif dan sistematis serta mendapat respon lisan dari peserta didik sehingga dapat menumbuhkan minat belajar dan pengetahuan baru dalam proses pembelajaran dengan menggunakan metode tanya jawab ini akan menarik perhatian peserta didik dan suasana kelas menjadi aktif.

Berdasarkan studi pendahuluan yang penulis lakukan di sekolah SMP NEGERI 3 Simpang Raya Kecamatan Singingi Hilir Kabupaten Kuansing maka diketahui gejala-gejala antara lain: (1) Guru telah menggunakan metode tanya jawab namun Peserta didik kurang merespon menjawab pertanyaan yang diberikan oleh guru; (2) Guru telah menggunakan metode tanya jawab namun Peserta didik merasa jenuh dalam pembelajaran; dan (3) Guru telah menggunakan metode tanya jawab namun Peserta didik kurang memperhatikan guru dalam pembelajaran

\section{METODE}

Berdasarkan latar belakang masalah, maka peneliti membatasi penelitian ini pada "hubungan metode tanya jawab dengan minat belajar peserta didik padamatapelajaran pendidikan agama Islam kelas VIII di SMP Negeri 3 Simpang Raya Kecamatan Singingi Hilir Kabupaten Kuansing".

Dengan memperhatikan pembatasan masalah di atas, maka perumusan masalah pada penelitian ini adalah "bagaimana hubungan metode tanya jawab dengan minat belajar peserta didik pada mata pelajaran pendidikan agama Islam kelas VIII Di SMP Negeri 3 Simpang Raya Kecamatan Singingi Hilir Kabupaten Kuansing ?".

Adapun tujuan penelitian ini adalah untuk mengetahui hubungan yang signifikan antara metode tanya jawab dengan minat belajar peserta didik pada mata pelajaran pendidikan agama Islam kelas VIII di SMP Negeri 3 Simpang Raya Kecamatan Singingi Hilir Kabupaten Kuansing.

\section{KONSEP TEORI \\ Hakikat Metode Tanya Jawab}

Istilah metode sering kali disamakan dengan istilah pendekatan, dan teknik/strategi sehingga dalam penggunaanya juga sering saling bergantian yang pada intinya adalah suatu cara untuk mencapai tujuan pendidikan yang ditetapkan, atau cara yang tepat dan cepat untuk meraih tujuan pendidikan sesuai dengan kebutuhan peserta didik (Novan Ardy Wiyani \& Barnawi, 2012:185). Metode pendidikan adalah bagaimana cara yang tepat isi atau materi pendidikan itu dididik atau diajarkan. Sedangkan isi atau materi pendidikan dijabarkan dari tujuan pendidikan dan diorganisasi menjadi kurikulum (Suparlan Suhartono, 2009:120).

Metode berarti cara kerja yang bersistem untuk memudahkan pelaksanaan suatu kegiatan guna mencapai tujuan yang di tetapkan. Menurut Syaiful Bahri Djamarah, metode adalah suatu cara yang dipergunakan untuk mencapai tujuan yang telah di tentukan. Dalam konsep pendidikan islam, metode pendidikan diartikan dengan beberapa istilah, yaitu(1) minhaj al-tarbiyah, (2) kayfiyah al-tabiyah, (3)wasilah altarbiyah, (4)at-thariqotu at-tarbiyah, sedangkan yang paling populer di gunakan adalah istilah, yang berarti jalan atau cara yang harus di tempuh. 
Menurut Zakiyah Darajat, metode ini di maksudkan agar murid dapat menangkap pelajaran dengan mudah efektif dan dapat di cerna oleh anak dengan baik. Metode dalam bahasa Arab, dikenal dengan istilah thariqah yang berarti langkah-langkah strategis dipersiapkan untuk melakukan suatu pekerjaan. Bila di hubungkan dengan pendidikan, maka strategi tersebut haruslah di wujudkan dalam proses pendidikan, dalam rangka pengembangan sikap dan mental dan kepribadian agar peserta didik menerima materi ajar dengan mudah, dan dapat di cerna dengan baik. Metode dapat diartikan sebagai cara yang di pergunakan oleh guru dalam mengadakan hubungan dengan peserta didik pada saat berlangsungnya proses proses pembelajaran. Dengan demikian, metode mengajar merupakan alat untuk menciptakan proses pembelajaran.

Menurut Hamzah B.Uno, ada tiga prinsip yang perlu dipertimbangkan dalam upaya menetapkan metode pembelajaran. Ketiga prinsip tersebut adalah (a) tidak ada satu metode pembelajaran yang unggul untuk semua tujuan dalam semua kondisi, (b) metode (strategi) pembelajaran yang berbeda memiliki pengaruh yang berbeda dan konsisten pada hasil pembelajaran, (c) kondisi pembelajaran bisa memiliki pengaruh yang konsisten pada hasil pengajaran. Dalam kegiatan pembelajaran guru tidak harus terpaku dengan satu metode tetapi guru sebaiknya menggunakan metode yang bervariasi agar pengajaran tidak membosankan tetapi menarik perhatian anak didik. Tetap penggunaan metode yang bervariasi tidak akan menguntungkan kegiatan pembelajaran bila penggunaanya tidak tepat sesuai situasi yang mendukungnya dan dengan kondisi psikologi anak didik. Oleh karena itu disinilah profesionalitas guru diperlukan dalam pemilihan metode yang tepat. Pemilihan dan penggunaan metode yang bervariasi tidak selamanya menguntungkan bila guru mengabaikan faktor-faktor yang mempengaruhi penggunaanya (Ramayulis, 2013:191).

Metode adalah cara yang digunakan untuk mengimplementasikan rencana yang sudah disusun dalam kegiatan yang nyata agar tujuan yang telah disusun tercapai secara optimal. Ini berarti, metode digunakan untuk merealisasikan strategi yang telah ditetapkan strategi yang telah ditetapkan. Dengan demikian, metode dalam rangkaian sistem pembelajaran memegang peran yang sangat penting (Wina Sanjaya, 2010:147).

Dalam hal ini terdapat pula ayat yang menggambarkan adanya metode tanya jawab yang bersumber dari AlQur'an. Ayat ini menggambarkan pertanyaan yang terkait dengan akidah manusia. Akidah yang berhubungan dengan Tuhan manusia dengan memberikan pertanyaan pada manusia siapa Tuhan itu melalui ciptaan langit dan bumi serta segala isinya dilihat dalam firman Allah SWT:

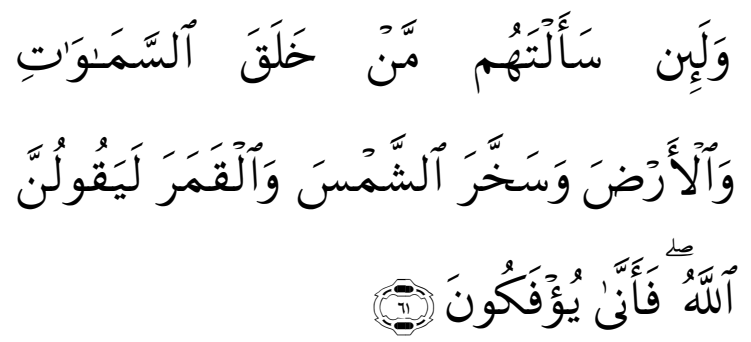

Artinya : Dan sesungguhnya jika kamu tanyakan kepada mereka: "Siapakah yang menjadikan langit dan bumi dan menundukkan matahari dan bulan?"tentu mereka akan menjawab :Allah, Maka betapakah mereka (dapat) dipalingkan (dari jalan yang benar". (QS. Al-Ankabut 61). 
Metode tanya jawab menurut Abuddin Nata dalam Syahraini Tambak adalah cara penyajian pelajaran dalam bentuk pertanyaan, yang di kemukakan oleh peserta didik. Metode tanya jawab menurut Darwyan syah,et.al, dalam Syahraini Tambak adalah cara penyajian pengajaran oleh guru dengan memberikan pertanyaan dan meminta jawaban kepada peserta didik. Sementara menurut Ramayulis dalam Syahraini Tambak, metode tanya jawab adalah suatu cara mengajar di mana seorang guru mengajukan beberapa pertanyaan kepada peserta didik tentang bahan pelajaran yang telah diajarkan atau bahan bacaan yang telah mereka baca sambil memperhatikan proses berfikir diantara peserta didik. Metode tanya jawab menurut Syahraini Tambak adalah cara penyampaian bahan materi pembelajaran pendidikan agama islam melalui bentuk pertanyaan yang harus dijawab oleh peserta didik baik berasal dari guru pendidikan agama islam maupun dari peserta didik itu sendiri untuk mencapai kompetensi pembelajaran yang telah ditetapkan sacara maksimal (Syahraini Tambak, 2014:283). Metode Tanya Jawab adalah suatu metode dimana guru menggunakan/memberi pertanyaan kepada murid dan murid menjawab, atau sebaliknya murid bertanya pada guru dan guru menjawab pertanyaan murid itu (Soetomo, 1993:150). Metode tanya jawab adalah metode mengajar yang memungkinnkan terjadinya komunikasi langsung yang bersifat dua arah sebab pada saat yang sama terjadi dialog antara guru dan siswa. Guru bertanya siswa menjawab, atau siswa bertanya guru menjawab. Dalam komunikasi ini terlihat adanya hubungan timbal balik secara langsung antara guru dengan siswa(Ibrahim dan Nana syaodih, 2003: 106). Metode tanya jawab adalah metode mengajar yang memungkinkan terjadinya komunikasi langsung yang bersifat two way trafficsebab pada saat yang sama terjadi dialog antara guru dan siswa. Guru bertanya siswa menjawab. Dan komunikasi ini terlihat adanya hubungan timbal balik secara langsung antara guru dengan siswa(Nana sudjana, 2002:78).

Dari pengertian di atas penulis dapat menyimpulkan bahwa metode tanya jawab adalah suatu cara mengajar seorang guru di mana adanya umpan balik antara guru dan peserta didk dalam pembelajaran dengan cara guru memberikan suatu pertanyaan dan pertanyaan tersebut di jawab oleh peserta didik yang telah di tunjuk untuk menjawab pertanyaan tersebut, begitu juga sebaliknya ini juga untuk memudahkan peserta didik apabila belum paham dengan materi tersebut maka bisa menanyakan pada guru tersebut.

Kelebihan dan kekurangan metode tanya jawab

Walaupun guru sudah menyiapkan secara sungguh-sungguh tentang pelaksanaan metode tanya jawab, tetapi tanya jawab tidak terlepas dari beberapa keuntungan. Keuntungan penggunaan metode tanya jawab adalah: (1) Suasana lebih menjadi aktif; (2) Anak mendapat kesempatan baik secara individu maupun kelompok untuk menanyakan hal-hal yang belum di mengerti; (3) Guru dapat mengetahui bagaimana penguasaan anak terhadap materi yang sedang di sampaikan, bagaimana anak sudah mengerti dan bagaimana anak belum menguasai; dan (4) Mendorong anak untuk berani mengajukan pendapatnya.

Adapun kelemahan metode tanya jawab ini adalah: (1) Pertanyaan dari guru sering menuju kepada pertanyaan yang sifatnya menghafal; (2) Tanya jawab kalau dilakukuan 
secara terus menerus akan dapat menyimpang dari bahan pokok bahasan yang sedang dipelajari; dan (3) Guru tidak dapat mengetahui secara pasti apakah anak tidak mengajukan pertanyaan itu telah memahami dan menguasai materi yang telah di berikan (Soetomo, 1993:153).

\section{Langkah-langkah Metode Tanya Jawab}

Menurut Tambak, untuk memberikan petunjuk yang jelas tentang penggunaan metode tanya jawab dalam pembelajaran pendidikan agama Islam diperlukan sebuah desain yang sekaligus menjadi kerangka pedoman dalam menggunakan metode ini. Desain metode tanya jawab dalam pendidikan agama islam adalah sebagai berikut:

Langkah pertama, tentukan tujuan pembelajaran metode tanya jawab melalui analisis indikator. Pada tahap ini seorang guru pendidikan agama islam harus terlebih dahulu menentukan tujuan pembelajaran yang akan dicapai melalui metode tanya jawab. Tujuan pembelajaran ini searah dengan hasil analisis terhadap indikator pembelajaran yang telah ditentukan. Analisis terhadap indikator pembelajaran sangatlah penting untuk menentukan ketepatan pengunaan metodetanya jawab yang dipergunakan. Tak jarang seorang guru pendidikan agama islam keliru menerapkan metode pengajaran karena tidak relevan dengan indikator pembelajaran.

Pada tahap ini guru PAI harus memberikan dan melakukan hal-hal penting yang menjadi panduan yaitu; (1)bertanya kepada peserta didik tentang materi yang sebelumnya dipelajari; (2) meminta satu atau dua orang peserta didik memberi komentar pembelajaran sebelumnya; (3)menyampaikan tujuan pembelajaran dengan metode tanya jawab; dan (4) menyampaikan indikator pembelajaran pada peserta didik dan menanyakan pemahaman awal mereka terhadap indikator pembelajaran yang telah disampaikan tersebut.

Langkah kedua, mengelola perhatian peserta didik. Setelah peserta didik diberikan apa yang menjadi tujuan dari metode tanya jawab yang disesuaikan dengan indikator pembelajaran, maka selanjutnya guru PAI harus sampai pada proses pengelolaan perhatian peserta didik.

Pada tahap ini hal penting yang harus dilakukan oleh guru PAI dalam menggunakan metode tanya jawab adalah; (1) memberikan motivasi sesuai dengan karakter materi yang akan diajarkan dan karakter bangsa yang telah di tetapkan; (2) body language yang energik yang menggambarkan semangat tinggi dalam mempengaruhi peserta didik untuk ikut dalam pembelajaran yang akan dilangsungkan; (3) intonasi suara yang menggambarkan munculnya semangat untuk membawa peserta didik mengikuti pembelajaran. Intonai suara guru pendidikan agama islam dimaksudkan untuk membangun motivasi dan semangat peserta didik. Suara guru yang monoton dan lemah ,tidak menarik perhatian peserta didik. (4) Menjaga kontak pandang dengan anak secara merata, Sehingga setiap anak merasa memperoleh perhatian. (5) Mengekspresikan mimik dengan ekspresi tertentu yang menggambarkan makna tertentu. Ekspresi mimik dapat digunakan pula untuk menggambarkan antusiasme dan keyakinan guru terhadap materi yang akan diajarkan.

Langkah ketiga, distribusi materi. Guru pendidikan agama islam harus mendistribusikan bahan ajar pendidikan agama islam berupa hand out atau lainnya pada peserta didik. Distribusi materi bukanlah membagibagi materi pada peserta didik dalam beberapa kelompok, akan tetapi materi 
itu diberikan pada peserta didik pada bentuk kelompok.

Hal yang perlu dilakukan secar maksimal oleh guru PAI pada tahapan ini adalah; (1) menyampaikan materi dalam bentuk lembaran (hand out) pada semua peserta didik sesuai dengan indikator pembelajaran yang akan di pelajari; (2) menyuruh peserta didik untuk membaca dan memahami materi tersebut secara individu dibangku masing-masing dalam waktu yang singkat; (3) menyuruh peserta didik untuk menuliskan hal-hal yang tidak dipahami dalam kertas kerja mereka; (4) meminta peserta didik untuk mempersiapkan pertanyaan yang memungkinkan untuk ditanyakan pada guru; (5) menyuruh peserta didik untuk mengingat garis besar pemahaman mereka tentang materi yang telah didistribusikan tersebut.

Langkah keempat, menggali pemahaman peserta didik. Mintalah peserta didik mengutarakan apa yang dipahami dan yang belum dipahami. Disini seorang guru pendidikan agama islam harus dapat menggali keberanian peserta didik untuk mengutarakan sesuatu yang dipahami dan yang belum dipahami terkait dengan materi yang akan diajarkan.

Langkah penting yang harus diterapkan oleh guru PAI pada tahapan ini adalah; (1) Meminta peserta didik untuk mengutarakan apa saja yang dipahami dari materi yang didistribusikan; (2) Meminta peserta didik untuk mengutarakan apa saja yang belum dipahami dari materi yang telah didistribusikan; (3) Meminta peserta didik mengemukakan apa yang menjadi kendala dalam memahami materi yang telah didistribusikan; (4) Guru memberikan komentar singkat terhadap pemahaman maupun tanggapan peserta didik tentang materi yang mereka baca.
Langkah kelima, mengajukan pertanyaan. Mengajukan pertanyaan ini merupakan inti dari langkah penggunaan metode tanya jawab. Guru pandidikan agama Islam mengajukan pertanyaan kepada seluruh peserta didik terkait dengan materi yang telah mereka baca sesuai dengan indikator pembelajaran.

Ada beberapa teknik yang dapat dipergunakan guru pada tahap ini dalam menggunakan metode tanya jawab bagi suksesnya pembelajaran pendidikan agama Islam yang dilakukan yaitu: (1) Memberikan pertanyaan pada peserta didik; (2) Klarifikasi pertanyaan; (3) Memberikan waktu pada pesrta didik untuk berfikir dan menyusun jawaban; (4) Meminta peserta didik untuk menjawab pertanyaan; (5) Pemindahan giliran (rediracting); (6) Pemberian tuntunan (Promting); dan (7) Guru memberikan jawaban.

Langkah keenam, Membuat kesimpulan bersama. Kesimpulan dalam setiap pembelajaran sangatlah dibutuhkan dan oleh karena itu kesimpulan harus dibuat secara bersama-sama.

Pada tahap ini hal yang dilakukan oleh seorang guru PAI dapat menggunakan langkah-langkah krusial yaitu: (1) Meminta peserta didik untuk memberikan kesimpulan terhadap materi yang diajarkan dimulai dari masing-masing indikator pembelajaran; (2) Meminta peserta didik yang lainnya untuk melengkapi kesimpulan yang telah dikemukakanpesera didik sebelumnya; (3) Guru bersama peserta didik mengklasifikasi kesimpulan tersebut sesuai dengan indikator pembelajaran; dan (4) Meminta pada peserta didik untuk menuliskan garis besar kesimpulan pembelajaran sesuai dengan indikator pembelajaran pada kertas kerja mereka. 
Langkah ketujuh, Mengadakan evaluasi. Setelah diadakan kesimpulan, maka selanjutnya adalah mengadakan evaluasi terhadap penguasaan materi peserta didik dan juga keberhasilan penggunaan metode tanya jawab yang dilaksanakan (Syahraini Tambak, 2014:295).

\section{Hakikat Minat belajar Pengertian Minat}

$\begin{array}{crr}\text { Minat } & \text { (interest), } & \text { yaitu } \\ \text { kecenderungan } & \text { individu } & \text { untuk }\end{array}$ melakukan sesuatu perbuatan. Minat adalah aspek yang dapat menentukan motivasi seseorang untuk melakukan aktivitas tertentu (Wina Sanjaya, 2010:71). Minat adalah suatu rasa lebih suka dan rasa keterikatan pada suatu hal atau aktivitas, tanpa ada yang menyuruh. Minat pada dasarnya adalah penerimaan akan suatu hubungan antara diri sendari dengan sesuatu di luar diri. Semakin kuat atau dekat hubungan tersebut, semakin besar minat (Slameto, 2010:180).

Minat secara sederhana, minat (interest) mengandung kecenderungan dan kegairahan yang tinggi atau keinginan yang besar terhadap sesuatu. Menurut (Reber syah, 2003) minat bukanlah istilah yang populer dalam psikologi disebabkan ketergantungannya terhadap berbagai faktor lainnya, seperti pemusatan perhatian, keingintahuan, motivasi , dan kebutuhan. Namun lepas dari kepopulerannya, minat sama halnya dengan kecerdasan dan motivasi, karena memberi pengaruh terhadap aktivitas belajar, ia akan tidak bersemangat atau bahkan tidak mau belajar. Oleh karena itu, dalam konteks belajar di kelas seorang guru atau pendidik lainnya perlu membangkitkan minat belajar tersebut banyak cara yang bisa di gunakan. Antara lain pertama dengan membuat materi yang akan dipelajari semenarik mungkin dan tidak membosankan baik dari bentuk buku materi dan desain (Rahmah, 2013:45).

Minat adalah rasa lebih suka dan rasa lebih keterikatan pada suatu hal atau aktivitas, tanpa ada yang menyuruh.minat pada dasarnya adalah penerimaan akan suatu hubungan antara diri sendiri dengan sesuatu diluar diri. Semakin kuat atau kuat hubungan tersebut, semakin besar minatnya (Djaali, 2009:121).

\section{Pengertian belajar}

Belajar secara umum diartikan sebagai perubahan pada individu yang terjadi melalui pengalaman dan bukan karena pertumbuhan atau perkembangan tubuhnya atau karakteristik seseorang sejak lahir. Manusia banyak belajar sejak lahir dan bahkan ada yang berpendapat sebelum lahir. Bahwa antara belajar dan perkembangan sangat erat kaitannya (Trianto, 2010:16). Belajar merupakan tindakan dan prilaku siswa yang kompleks. Sebagai tindakan, maka belajar hanya dialami oleh siswa sendiri. Siswa adalah penentu terjadinya atau tidak terjadinya proses belajar. Proses belajar terjadi berkat siswa memperoleh sesuatu yang ada di lingkungan sekitar (Dimyati dan Modjiono, 2006:7).

Menurut HC Witherington memberi batasan: Belajar adalah suatu perubahan didalam kepribadian yang menyatukan diri sebagai suatu pola baru dari reaksi yang berupa kecakapan, sikap, kebiasaan, kepandaian, atau suatu pengertian (Soetomo, 1993:119).

Dari beberapa penjelasan minat dan belajar diatas dapat penulis simpulkan bahwa Minat belajar ini sangatlah penting bagi peserta didik karena dapat menumbuhkan semangat dalam belajar, apabila tidak ada minat 
belajar maka akan sulit untuk memahami materi pelajaran yang ada, apabila peserta didik memiliki minat yang tinggi dalam belajar dan apabila ia bisa memahami materi yang telah dijelaskan oleh guru maka itu akan memudahkan guru dalam mengajar. Dan adanya minat belajar itu karena adanya keinginan yang besar ataupun kegigihan peserta didik dalam belajar dan nantinya akan memberikan nilai positif bagi peserta didik yang serius dalam belajar.

\section{METODE}

Adapun jenis penelitian ini adalah penelitian korelasional yang dimaksudkan untuk mencari atau menguji hubungan antara dua variabel. Penelitian korelasional bertujuan mengungkapkan hubungan korelatif antar variabel. Hubungan korelatif mengacu pada kecenderungan bahwa variasi suatu variabel diikuti variasi yang lain. Dengan demikian, dalam rancangan penelitian korelasional peneliti melibatkan minimal dua variabel.
Penelitian dilakukan di SMP Negeri 3 Simpang Raya Kecamatan Singingi Hilir Kabupaten Kuansing. Dan penelitian ini di laksanakan selama 4 bulan (bulan Januari sampai bulan April 2016).

Subjek penelitian ini adalah peserta didik kelas VIII pada bidang studi pendidikan agama Islam di SMP Negeri 3 Simpang Raya Kecamatan Singingi Hilir Kabepaten Kuansing. Sedangkan objek penelitian ini adalah Hubungan metode tanya jawab dengan minat belajar peserta didik pada mata pelajaran Pendidikan agama Islam di SMP Negeri 3 Simpang Raya Kecamatan Singingi Hilir Kabupaten Kuansing.

Populasi dalam penelitian ini adalah seluruh peserta didik kelas VIII SMP Negeri 3 berjumlah 119 orang Kecamatan Singingi Hilir Kabupaten Kuansing. Mengingat jumlahnya populasi penelitian terlalu banyak, maka penulis menetapkan untuk mengambil sampel penelitian berjumlah 59 orang dengan rincian sebagai berikut

Tabel 1 : Populasi dan Sampel Penelitian

\begin{tabular}{ccccc}
\hline NO & Keterangan & Populasi & Sampel & Persentase \\
\hline 1. & Kelas VIII A & 32 & 16 & $20 \%$ \\
\hline 2. & Kelas VIII B & 30 & 15 & $20 \%$ \\
\hline 3. & Kelas VIII C & 29 & 14 & $20 \%$ \\
\hline 4. & Kelas VIII D & 28 & 14 & $20 \%$ \\
\hline & Jumlah & $\mathbf{1 1 9}$ & $\mathbf{5 9}$ & \\
\hline
\end{tabular}

Dalam pengumpulan data, ada yang di sebut dengan data primer yaitu data yang di kumpulkan sendiri secara langsung oleh peneliti dan ada pula yang dinamakan data skunder yaitu data yang telah dikumpulkan oleh orang lain. Adapun tekhnik pengumpulan data primer yang digunakan dalam penelitian ini adalah angket, sedangkan untuk data sekunder tekhnik pengumpulan datanya di gunakan dokumentasi.

Pengolahan data dilakukan setelah data terhimpun dan telah dapat memberikan gambaran yang menyeluruh tentang objek penelitian. Tahap-tahap pengolahan data dilakukan sebagai berikut: (1) Penyuntingan (editing), data yang telah dikumpulkan mengenai penelitian ini akan di periksa 
dengan cara mengkoreksi atau melakukan pengecekan untuk memperoleh data yang dipertanggungjawabkan;

Pengkodean (coding), yaitu pemberian data, simbol, dan kode bagi tiap data yang termasuk dalam kategori yang sama. Tanda ini dapat berupa angka atau huruf; (3) Tabulasi(tabulating), jawaban-jawaban yang serupa dikelompokkan dikategorikan. Kegiatan tersebut dilaksanakan sampai terwujud tabel-tabel yang berguna, terutama penting pada data kuantitatif; dan (4) Skoring, memberikan skor terhadap butir-butir pertanyaan yang terdapat dalam angket setelah penulis melakukan tahap editing. Butir jawaban yang terdapat dalam angket ada 5 (lima). Adapun pemberian skor untuk setiap jawaban adalah: Sangat kuat(SK) skor 5 (lima), kuat (K) skor 4 (empat), sedang ((S) skor 3 (tiga), rendah (R) skor 2 (dua), sangat rendah (SR) skor 1 (satu). (Rizal Dairi, 2012 : 78-80).

Sebelum penelitian dilaksanakan maka langkah yang utama adalah melakukan uji coba instrumen penelitian.Uji coba dari butir-butir instrumen pada kedua variabel dimaksudkan untuk menguji keabsahan dan kehandalan butir-butir instrumen yang digunakan dalam penelitian.Untuk itu hasil uji coba harus dicari validitas dan reabilitasnya.

Dalam penelitian ini validitas instrumen diuji dengan menggunakan bantuan SPSS 20 dengan metode korelasi product moment. Teknik uji validitas instrumen dengan korelasi product moment yaitu dengan cara mengkorelasikan skor tiap item dengan skor total yang merupakan jumlah tiap skor item.

Menurut Duwi Priyatno (2014: 55), untuk menentukan apakah itemitemdari setiap instrumen valid atau tidak valid maka dapat dilakukan dengan dua cara yaitu: (1) Dilihat pada nilai signifikansi. Jika signifikansi kurang dari 0,05 maka item valid, tetapi jika signifikansi lebih dari 0,05 maka item tidak valid; dan

Membandingkan $r$ hitung (nilai pearson correlation) dengan $r$ tabel (didapat dari tabel $r$ ). Jika nilai positif dan $r$ hitung $\geq$ maka item dapat dinyatakan valid. Jika $r$ hitung $\leq \mathrm{r}$ tabel, maka item dinyatakan tidak valid, $\mathrm{r}$ tabel pada tingkat signifikansi 0,05 dengan uji 2 sisi.

Dalam penelitian ini uji reabilitas instrumen dilakukan dengan internal consistency yaitu mencobakan instrumen sekali saja, kemudian data yang diperoleh dianalisis dengan teknik tertentu.Hasil analisisnya dapat digunakan untuk memprediksi reabilitas instrumen.

Pengujian instrumen dapat dilakukan dengan menggunakan bantuan program SPSS 20. Uji reabilitas dilakukan dengan menggunakan metode Cronbach alpha.Dalam metode ini item yang valid saja yang masuk pengujian.Untuk menentukan apakah instrumen reliabel atau tidak menggunakan batasan yang reabilitas kurang dari 0,6 adalah kurang baik, sedang 0,7 dapat diterima dan diatas 0,8 adalah baik (Duwi Priyatno,2014:64).

Dalam penelitian ini uji asumsi dilakukan sebagai persyaratan untuk menentukan jenis statistik yang akan digunakan dalam analisis penelitian yang menggunakan metode kuantitatif dalam mengolah data penelitiannya.

Uji normalitas berguna untukmenentukan apakah data yang telah dikumpulkan berdistribusi normal atau tidak.Normalitas data merupakan syarat pokok yang harus dipenuhi dalam analisis parametrik.Normalitas data merupakan hal yang penting karena dengan data yang terdistribusi normal, maka data tersebut dianggap dapat mewakili populasi. 


\begin{abstract}
Dalam penelitian ini uji normalitas dilakukan dengan menggunakan bantuan program SPSS 20 yang dilakukan dengan metode one sample kolmogorov-smirnov. Dengan kriteria pengujiannya adalah jika signifikansi $<0,05$, maka kesimpulannya data tidak berdistribusi normal, jika signifikansi > 0,05 maka data berdistribusi normal (Duwi Priyatno, 2014:78).
\end{abstract}

Uji linieritas digunakan untuk mengetahui linieritas data yaitu apakah dua variabel mempunyai hubungan yang linier secara signifikansi atau tidak.Data yang baik seharusnya terdapat hubungan yang linier antara variabel independent (X) dengan variabel dependent (Y). Uji ini digunakan sebagai persyaratan dalam analisis korelasi pearson atau regresi linier (Duwi Priyatno, 2014:79).

Uji linieritas dalam penelitian ini menggunakan program SPSS 20 dengan cara test for linearity pada taraf signifikansi 0,05. Dua variabel dikatakan mempunyai hubungan yang linier bila signifikansi (linearity) kurang dari 0,05 . Teori ini mengatakan bahwa dua variabel mempunyai hubungan yang linear bila signifikansi (Deviation for linearity) lebih dari 0,05 (Duwi Priyatno, 2014:79).

Analisis korelasi pearson atau dikenal juga dengan korelasi product moment adalah untuk mengukur keeratan hubungan linier antara dua variabel yang mempunyai distribusi data normal.(Duwi Priyatno, 2014:123).

Untuk menganalisis data tentang hubungan metode tanya jawab dengan minat belajar peserta didik, dan untuk menentukan apakah variabel $\mathrm{X}$ dengan variabel $Y$ terdapat hubungan yang signifikan, maka peneliti menggunakan rumus korelasi product moment yaitu:

$$
\begin{aligned}
& R_{x y} \\
& \sqrt{\left[n \cdot \sum X^{2}-\left(\sum X\right)^{2}\right] \cdot\left[n \cdot \sum Y^{2}-\left(\sum Y\right)^{2}\right]}
\end{aligned}
$$

Keterangan:

$r_{x y}=$ Angka indeks korelasi antara variabel $\mathrm{X}$ dan variabel $\mathrm{Y}$

$\mathrm{n}=\quad$ Jumlah sampel

$\sum X^{2}=$ Jumlah kuadrat variabel $X$

$\sum Y^{2}=$ Jumlah kuadrat variabel $Y$

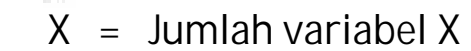

$\sum \mathrm{Y}$ m=

$\mathrm{X} \operatorname{dan} \mathrm{Y}$

$\sum X Y$ XIIJumlah[perkalian_antara_yariabel

Kemudian untuk pengujian signifikansi antara variabel $\mathrm{X}$ dengan variabel $\mathrm{Y}$ dilakukan dengan kriteria menggunakan $r$ tabel pada tingkat signifikansi 0,05 . Jika nilai positif dan $r$ hitung $\geq r$ tabel maka terdapat hubungan yang signifikansi antara variabel $\mathrm{X}$ dan variabel $\mathrm{Y}$, jika $\mathrm{r}$ hitung $<$ $r$ tabel maka tidak terdapat hubungan yang signifikansi antara variabel $\mathrm{X}$ dan Y.

Ketentuan nilai $\mathrm{r}$ tidak boleh dari harga $(-1 \leq \mathrm{r} \leq+1)$. Maksudnya adalah nilai $\mathrm{r}$ terbesar adalah $=1$ dan nilai $\mathrm{r}$ terkecil adalah -1. Apabila $r=-1$ Artinya korelasinya negatif sempurna; $r=0$ artinya tidak ada korelasi; dan $r=1$ artinya korelasinya sangat kuat (Riduan dan Akdon,2013:124).

\section{HASIL DAN PEMBAHASAN Gambaran Umum Lokasi Penelitian}

SMP Negeri 3 Singingi Hilir dididirikan pada tahun 1989 dan telah meluluskan/menamatkan peserta didik 26 periode. SMP Negeri 3 Singingi Hilir terletak diatas tanah seluas $\pm 12.046 \mathrm{M}^{2}$ yang pada keseluruhannya berada diatas bebatuan, serta berbatasan dengan pasar desa, perumahan, tanah (kebun) penduduk,Lapangan sepak bola, lapangan voli, kantor desa, gedung serba guna, Bidan desa, KUD, BUMDES, 
SDN 005, sekolah SPS, PAUD, TK NUSANTARA, TPQ MANBA'UL 'ULUM, MDA AS-SYIFA WA'AIN.

Visi SMP Negeri 3 Singingi Hilir, yaitu: "Mewujudkan pendidikan berkualitas, bertaqwa,dan berakhlaq mulia serta menciptakan lingkungan yang sehat dan bersih." Sedangkan misi SMP Negeri 3 Singingi Hilir, yaitu: (1) Meningkatkan ilmu pengetahuan, dan teknologi; (2) Meningkatkan kualitas lulusan untuk dapat bersaing pada sekolah unggulan atau favorit: (3) Melaksanakan norma-norma ajaran agama di sekolah maupun di masyarakat; (4) Menerapkan pola pendidikan yang berkarakter; (5) Menumbuhkembangkan disiplin, solidaritas, saling menghargai dan menghormati serta tetap menjaga hubungan yang harmonis antar sesama; dan (6) Melaksanakan program $10 \mathrm{~K}$.

\section{Hubungan Metode Tanya Jawab Dengan Minat Belajar Peserta Didik}

Penelitian ini merupakan penelitian lapangan, oleh sebab ini data yang akan disajikan dalam bab ini adalah data yang dikumpulkan dari lapangan. Adapun tehnik pengumpulan data yang digunakan untuk memperoleh data tersebut adalah dengan menggunakan angket.

Hasil angket ini diharapkan menunjukkan bagaimana tingkat hubungan metode tanya jawab dengan minat belajar peserta didik pada mata pelajaran pendidikan agama Islam Di SMP NEGERI 3 Simpang Raya Kecamatan Singingi Hilir Kabupaten Kuansing. Angket ini diberikan kepada 59 responden yang menjadi sampel dalam penelitian ini. Kemudian data akan disajikan dalam bentuk tabel. Hal ini dilakukan untuk mempermudah penyajian data dari hasil angket tersebut dapat dilihat pada tabel berikut:

Tabel 2 :Rekapitulasi Hasil Angket Metode Tanya Jawab (Variabel X)

\begin{tabular}{clllllcc}
\hline No & \multicolumn{1}{c}{ Pertanyaan } & SS & S & KK & K & TP & Jumlah \\
\hline 1 & $\begin{array}{l}\text { Guru bertany kepada peserta didik } \\
\text { tentang materi sebelumnya } \\
\text { dipelajari }\end{array}$ & 18 & 27 & 14 & 0 & 0 & 59 \\
\hline 2 & $\begin{array}{l}\text { Guru meminta satu atau dua orang } \\
\text { peserta didik memberi komentar } \\
\text { pembelajaran sebelumnya }\end{array}$ & 3 & 13 & 29 & 4 & 10 & 59 \\
\hline 3 & $\begin{array}{l}\text { Guru menyampaikan tujuan } \\
\text { pembelajaran dengan metode } \\
\text { tanya jawab }\end{array}$ & 19 & 30 & 2 & 2 & 6 & 59 \\
\hline 4 & $\begin{array}{l}\text { Guru menyampaikan } \\
\text { indikatorpembelajaran pada } \\
\text { peserta didik dan } \\
\text { menanyakanpemahaman awal } \\
\text { mereka terhadap indikator } \\
\text { pembelajaran yang telah } \\
\text { disampaikan tersebut }\end{array}$ & 14 & 28 & 5 & 2 & 10 & 59 \\
$\quad$ Pertanyaan & & & & & & \\
\hline No & & & & & & & \\
\hline 5 & $\begin{array}{l}\text { Guru memberikan motivasi sesuai } \\
\text { dengan karakter materi yang } \\
\text { diajarkan dan karakter bangsa }\end{array}$ & 13 & 24 & 10 & 6 & 6 & 59 \\
\hline
\end{tabular}




\begin{tabular}{|c|c|c|c|c|c|c|c|}
\hline & yang telah ditetapkan & & & & & & \\
\hline 6 & $\begin{array}{l}\text { Body language guru yang energi } \\
\text { menggambarkan semangat tinggi } \\
\text { dalam mempengaruhi peserta } \\
\text { didik untuk ikut dalam } \\
\text { pembelajaran yang akan } \\
\text { dilangsungkan }\end{array}$ & 12 & 27 & 10 & 5 & 5 & 59 \\
\hline 7 & $\begin{array}{l}\text { Intonasi suara guru yang } \\
\text { menggambarkan munculnya } \\
\text { semangat untuk membawa peserta } \\
\text { didik mengikuti pembelajaran }\end{array}$ & 21 & 18 & 16 & 5 & 0 & 59 \\
\hline 8 & $\begin{array}{l}\text { Guru mengekspresikan mimik } \\
\text { dengan ekspresi tertentu yang } \\
\text { menggambarkan makna tertentu }\end{array}$ & 10 & 27 & 14 & 5 & 3 & 59 \\
\hline 9 & $\begin{array}{l}\text { Guru menyampaikan materi dalam } \\
\text { bentuk(hand out) pada semua } \\
\text { peserta didik sesuai dengan } \\
\text { indikator pembelajaran yang akan } \\
\text { dipelajari }\end{array}$ & 7 & 30 & 10 & 8 & 4 & 59 \\
\hline 10 & $\begin{array}{l}\text { Guru menyuruh peserta didik } \\
\text { untuk menuliskan hal-hal yang } \\
\text { tidak dipahami dalam kertas kerja } \\
\text { mereka }\end{array}$ & 7 & 9 & 18 & 6 & 9 & 59 \\
\hline 11 & $\begin{array}{l}\text { Guru meminta peserta didik untuk } \\
\text { mempersiapkan pertanyaan yang } \\
\text { memungkinkan untuk ditanyakan } \\
\text { pada guru }\end{array}$ & 9 & 26 & 18 & 2 & 4 & 59 \\
\hline 12 & $\begin{array}{l}\text { Guru menyuruh peserta didik } \\
\text { untuk mengingat garis besar } \\
\text { pemahaman mereka tentang } \\
\text { materi yang telah didistribusikan } \\
\text { tersebut }\end{array}$ & 18 & 25 & 9 & 7 & 0 & 59 \\
\hline 13 & $\begin{array}{l}\text { Guru meminta peserta didik untuk } \\
\text { mengutarakan apa saja yang } \\
\text { dipahami dari materi yang } \\
\text { didistribusikan }\end{array}$ & 10 & 21 & 20 & 6 & 2 & 59 \\
\hline 14 & $\begin{array}{l}\text { Guru meminta peserta didik untuk } \\
\text { mengutarakan apa saja yang belum } \\
\text { dipahami dari materi yang telah } \\
\text { didistribusikan }\end{array}$ & 19 & 28 & 13 & 3 & 1 & 59 \\
\hline 15 & $\begin{array}{l}\text { Guru meminta peserta didik } \\
\text { mengemukakan apa yang menjadi } \\
\text { kendala dalam memahami materi } \\
\text { yang telah didistribusikan }\end{array}$ & 12 & 18 & 18 & 6 & 5 & 59 \\
\hline 16 & $\begin{array}{l}\text { Guru memberikan komentar } \\
\text { singkat terhadap pemahaman } \\
\text { maupun tanggapan peserta didik } \\
\text { tentang materi yang mereka baca }\end{array}$ & 10 & 28 & 12 & 7 & 2 & 59 \\
\hline
\end{tabular}




\begin{tabular}{|c|c|c|c|c|c|c|c|}
\hline 17 & $\begin{array}{l}\text { Guru memberikan pertanyaan } \\
\text { kepada peserta didik }\end{array}$ & 41 & 15 & 3 & 0 & 0 & 59 \\
\hline 18 & Guru mengklarifikasi pertanyaan & 21 & 29 & 9 & 0 & 0 & 59 \\
\hline 19 & $\begin{array}{l}\text { Guru memberikan waktu pada } \\
\text { peserta didik untuk berfikir dan } \\
\text { menyusun jawwaban }\end{array}$ & 30 & 23 & 4 & 1 & 1 & 59 \\
\hline 20 & $\begin{array}{l}\text { Guru meminta peserta didik untuk } \\
\text { menjawab pertanyaan }\end{array}$ & 30 & 25 & 4 & 0 & 0 & 59 \\
\hline 21 & Pemindahan giliran(rediracting) & 5 & 23 & 20 & 8 & 3 & 59 \\
\hline 22 & Pemberian tuntunan(promting) & 12 & 32 & 10 & 5 & 0 & 59 \\
\hline 23 & Guru memberikan jawaban & 16 & 19 & 17 & 4 & 3 & 59 \\
\hline 24 & $\begin{array}{l}\text { Guru meminta peserta didik untuk } \\
\text { memberikan kesimpulan terhadap } \\
\text { materi yang diajarkan dimulai dari } \\
\text { masing-masing indikator } \\
\text { pembelajaran }\end{array}$ & 10 & 28 & 13 & 5 & 3 & 59 \\
\hline 25 & $\begin{array}{l}\text { Guru meminta peserta didik yang } \\
\text { lainnya untuk melengkapi } \\
\text { kesimpulan yang telah } \\
\text { dikemukakan peserta didik } \\
\text { sebelumnya }\end{array}$ & 6 & 35 & 10 & 3 & 5 & 59 \\
\hline 26 & $\begin{array}{l}\text { Guru bersama peserta didik } \\
\text { mengklasifikasi kesimpulan } \\
\text { tersebut sesuai dengan indikator } \\
\text { pembelajaran }\end{array}$ & 6 & 32 & 16 & 0 & 5 & 59 \\
\hline 27 & $\begin{array}{l}\text { Gguru meminta pada peserta didik } \\
\text { untuk menuliskan garis besar } \\
\text { kesimpulan pembelajaran sesuai } \\
\text { dengan indikator pembelajaran } \\
\text { pada kertas kerja mereka }\end{array}$ & 5 & 23 & 22 & 4 & 5 & 59 \\
\hline 28 & $\begin{array}{l}\text { Guru mengadakan ealuasi terhadap } \\
\text { penguasaan materi peserta didik }\end{array}$ & 11 & 30 & 13 & 4 & 1 & 59 \\
\hline & JUMLAH & 395 & $\begin{array}{c}69 \\
3\end{array}$ & $\begin{array}{c}35 \\
9\end{array}$ & $\begin{array}{c}12 \\
0\end{array}$ & 93 & 1652 \\
\hline
\end{tabular}

Berdasarkan tabel 2 di atas terlihat bahwa jawaban peserta didik yang menyatakan sering lebih banyak yaitu 693, ini menunjukkaan guru telah menggunakan metode tanya jawab dengan baik. Dan hanya sebagian guru yang belum menggunakan metode tanya jawab dengan baik yang dapat dilihat dari jawaban peserta didik yang menyatakan tidak pernah yang paling sedikit yaitu 93.

Tabel 3 :Rekapitulasi Hasil Angket Minat Belajar Peserta Didik (Variabel Y)

\begin{tabular}{cccccccc}
\hline No & \multicolumn{1}{c}{ Pertanyaan } & SS & S & KK & K & TP & Jumlah \\
\hline 1 & Saya senantiasa mengatakan tertarik & 21 & 28 & 9 & 1 & 0 & 59 \\
$\begin{array}{l}\text { kepada pelajaran pendidikan agama } \\
\text { islam di sekolah maka saya akan } \\
\text { mendengarkan guru disaat }\end{array}$ & & & & & & \\
\hline
\end{tabular}




\begin{tabular}{|c|c|c|c|c|c|c|c|}
\hline \multicolumn{8}{|c|}{ menjelaskan pelajaran } \\
\hline 2 & $\begin{array}{l}\text { Saya senantiasa mengatakan tertarik } \\
\text { kepada pelajaran pendidikan agama } \\
\text { islam di sekolah maka saya akan } \\
\text { mencari-cari materi mana yang } \\
\text { masih belum dipahami }\end{array}$ & 17 & 28 & 7 & 5 & 2 & 59 \\
\hline 3 & $\begin{array}{l}\text { Saya senantiasa mengatakan tertarik } \\
\text { kepada pelajaran pendidikan agama } \\
\text { islam di sekolah maka saya akan } \\
\text { mengamalkan pelajaran itu }\end{array}$ & 13 & 27 & 16 & 2 & 1 & 59 \\
\hline 4 & $\begin{array}{l}\text { Saya senantiasa berminat terhadap } \\
\text { pelajaran pendidikan agama islam } \\
\text { maka saya harus berperan aktif } \\
\text { terhadap proses belajar mengajar }\end{array}$ & 17 & 21 & 17 & 4 & 0 & 59 \\
\hline 5. & $\begin{array}{l}\text { Saya senantiasa berminat terhadap } \\
\text { pelajaran pendidikan agama islam } \\
\text { maka saya harus giat belajar } \\
\text { terhadap proses belajar mengajar }\end{array}$ & 18 & 27 & 14 & 0 & 0 & 59 \\
\hline 6. & $\begin{array}{l}\text { Saya senantiasa berminat terhadap } \\
\text { pelajaran pendidikan agama islam } \\
\text { maka saya harus rajin mengerjakan } \\
\text { tugas }\end{array}$ & 3 & 13 & 29 & 4 & 10 & 59 \\
\hline 7. & $\begin{array}{l}\text { Saya senantiasa berminat terhadap } \\
\text { pelajaran pendidikan agama islam } \\
\text { maka saya harus rajin } \\
\text { memperhatikan pelajaran yang } \\
\text { sedang di jelaskan oleh guru }\end{array}$ & 19 & 30 & 2 & 2 & 6 & 59 \\
\hline 8. & $\begin{array}{l}\text { Saya senantiasa berminat terhadap } \\
\text { pelajaran pendidikan agama islam } \\
\text { maka saya harus rajin bertanya } \\
\text { dengan guru }\end{array}$ & 14 & 28 & 5 & 2 & 10 & 59 \\
\hline & JUMLAH & 122 & 202 & 99 & 20 & 29 & 472 \\
\hline
\end{tabular}

Berdasarkan tabel 3 di atas terlihat bahwa jawaban peserta didik yang menyatakan sering lebih banyak yaitu 202, ini menunjukkan peserta didik telah memiliki minat belajar dengan baik.Dan hanya sebagian peserta didik yang belum memiliki memiliki minat belajar dengan baik yang dapat dilihat dari jawaban peserta didik yang menyatakan tidak pernah yang paling sedikit yaitu 20 .

\section{Analisis Data Uji Validitas dan Reliabilitas}

Untuk menguji kehandalan dari angket yang digunakan dalam penelitian ini maka dilakukan uji validitas dan reliabilitas pada setiap variabel penelitian dengan tujuan untuk memperoleh data yang baik.

Adapun hasil pengujian validitas dan reliabilitas instrumen dapat dilihat pada rekapitulasi tabel berikut:

Tabel 4 : Hasil Rekapitulasi Validitas Variabel Metode Tanya Jawab (X)

\begin{tabular}{cccc}
\hline Pernyataan & $\begin{array}{c}\text { Nilai } \\
\text { Probabilitas }\end{array}$ & $\begin{array}{c}\text { Taraf Signifikansi } \\
(\boldsymbol{\alpha}=\mathbf{0 , 0 5})\end{array}$ & Keteragan \\
\hline P1 & 0.000 & 0,05 & Valid \\
\hline P2 & 0.000 & 0,05 & Valid \\
\hline
\end{tabular}




\begin{tabular}{cccc}
\hline P3 & 0.000 & 0,05 & Valid \\
\hline P4 & 0.001 & 0,05 & Valid \\
\hline P5 & 0.000 & 0,05 & Valid \\
\hline P6 & 0.000 & 0,05 & Valid \\
\hline P7 & 0.002 & 0,05 & Valid \\
\hline P8 & 0.154 & 0,05 & Tidak Valid \\
\hline P9 & 0.005 & 0,05 & Valid \\
\hline P10 & 0.000 & 0,05 & Valid \\
\hline P11 & 0.069 & 0,05 & Tidak Valid \\
\hline P12 & 0.000 & 0,05 & Valid \\
\hline P13 & 0.002 & 0,05 & Valid \\
\hline P14 & 0.000 & 0,05 & Valid \\
\hline P15 & 0.000 & 0,05 & Valid \\
\hline P16 & 0.000 & 0,05 & Valid \\
\hline P17 & 0.000 & 0,05 & Valid \\
\hline P18 & 0.001 & 0,05 & Valid \\
\hline P19 & 0.009 & 0,05 & Valid \\
\hline P20 & 0.003 & 0,05 & Valid \\
\hline P21 & 0.000 & 0,05 & Valid \\
\hline P22 & 0.005 & 0,05 & Valid \\
\hline P23 & 0.017 & 0,05 & Valid \\
\hline P24 & 0.006 & 0,05 & Valid \\
\hline P25 & 0.028 & 0,05 & Valid \\
\hline P26 & 0.000 & 0,05 & Valid \\
\hline P27 & 0.000 & 0,05 & Valid \\
\hline P28 & 0.000 & 0,05 & Valid \\
\hline P29 & 0.000 & 0,05 & Valid \\
\hline P30 & 0.005 & 0,05 & Valid \\
\hline & & & \\
\hline
\end{tabular}

Item dalam instrumen dikatakan valid jika signifikansi $<0,05$, tetapi jika signifikansi $>0,05$ item tidak valid.

Berdasarkan tabel 6 di atas, dari 30 pernyataan hanya 2 item pernyataan yang tidak valid. Karena memiliki nilai probabilitas atau signifikansi lebih besar > 0,05 yaitu item $8,(0,154>$ $0,05)$, dan item $11(0,069>0,05)$. Hasil ini diperoleh melalui SPSS 20, dengan demikian dalam penelitian ini hanya menggunakan 28 item pernyataan metode Tanya jawab.

Kemudian instrumen yang sudah valid diuji kembali dengan menggunakan SPSS 20 untuk mengetahui tingkat reliabilitasnya, di mana item yang masuk pengujian adalah item yang valid saja.

Adapun hasil uji instrumen tersebut dengan menggunakan SPSS 20 adalah sebagai berikut :

Tabel 5 : Hasil Uji Reliabilitas Variabel Metode Tanya Jawab (X) Reliability Statistics

\section{Cronbach's Alpha} 0,878

\section{N of Items}

28 
Berdasarkan tabel 5 di atas, dapat diketahui bahwa seluruh instrumen dinyatakan reliabel. Sesuai dengan teori yang telah dijelaskan pada bab III, sebuah instrumen dinyatakan reliabel jika hasil Cronbach's Alpha menunjukkan angka minimal 0,6 dan nilai Cronbach's Alpha pada tabel di atas adalah 0,878 dengan kriteria baik (memiliki konsistensi yang tinggi). Hal ini menunjukkan bahwa 0,878> 0,6 sehingga intrumen yang telah diuji dapat digunakan sebagai instrumen penelitian.

Tabel 6: Hasil Rekapitulasi Validitas Minat Belajar Peserta Didik (Y)

\begin{tabular}{cccc}
\hline Pernyataan & $\begin{array}{c}\text { Nilai } \\
\text { Probabilitas }\end{array}$ & $\begin{array}{c}\text { Taraf Signifikansi } \\
(\boldsymbol{\alpha}=\mathbf{0 , 0 5})\end{array}$ & Keterangan \\
\hline 1 & $\mathbf{2}$ & $\mathbf{3}$ & $\mathbf{4}$ \\
\hline P1 & 0,000 & 0,05 & Valid \\
\hline P2 & 0,000 & 0,05 & Valid \\
\hline P3 & 0,000 & 0,05 & Valid \\
\hline P4 & 0,000 & 0,05 & Valid \\
\hline P5 & 0,000 & 0,05 & Valid \\
\hline P6 & 0,000 & 0,05 & Valid \\
\hline P7 & 0,000 & 0,05 & Valid \\
\hline P8 & 0,000 & 0,05 & Valid \\
\hline
\end{tabular}

Item dalam instrumen dikatakan valid jika nilai probabilitas atau signifikansi $<0,05$, tetapi jika signifikansi $>0,05$ item tidak valid.

Berdasarkan tabel 8 di atas, dari 8 pernyataan semuanya valid. Karena nilai probabilitas atau signifikansi seluruh item pernyataan $<0,05$. Hasil ini diperoleh melalui SPSS 20, dengan demikian penelitian ini menggunakan 8 item pernyataan minat belajar peserta didik.

Kemudian instrumen yang sudah valid diuji kembali dengan menggunakan SPSS 20 untuk mengetahui tingkat reliabilitasnya, di mana item yang masuk pengujian adalah item yang valid saja.

Adapun hasil uji instrumen tersebut dengan menggunakan SPSS 20 adalah sebagai berikut :

Tabel 7 : Hasil Uji Reliabilitas Variabel Minat Belajar Peserta Didik (Y) Reliability Statistics

\begin{tabular}{c|c}
\hline Cronbach's Alpha & N of Items \\
\hline 0,658 & 8 \\
\hline
\end{tabular}

Berdasarkan tabel 7 di atas, dapat diketahui bahwa seluruh instrumen dinyatakan reliabel. Sesuai dengan teori yang telah dijelaskan pada bab III, sebuah instrumen dinyatakan reliabel jika hasil Cronbach's Alpha menunjukkan angka minimal 0,6 dan nilai Cronbach's Alpha pada tabel di atas adalah 0,658. Hal ini menunjukkan bahwa 0,658>0,6 sehingga intrumen yang telah diuji dapat digunakan sebagai instrumen penelitian. 


\section{Uji Asumsi}

\section{Uji Normalitas}

Uji normalitas dilakukan untuk menentukan apakah data yang telah dikumpulkan berdistribusi normal atau tidak. Dalam penelitian ini uij normalitas dilakukan dengan menggunakan program SPSS 20 dengan metode One Sample KolmogorovSmirnov. Untuk pengambilan keputusan apakah data normal atau tidak, maka cukup melihat pada nilai signifikansi (Asymp Sig 2-tailed). Jika signifikansi kurang dari 0,05, maka kesimpulannya data tidak berdistribusi normal. Jika signifikansi lebih dari 0,05, maka data berdistribusi normal.

Hasil perhitungan uji normalitas variabel X (Metode Tanya Jawab), dan Variabel Y (Minat Belajar Peserta Didik) dijelaskan dalam tabel berikut :

Tabel 8 : Hasil Perhitungan Uji Normalitas

\begin{tabular}{l|c|c|c|c}
\hline \multicolumn{5}{c}{ One-Sample Kolmogorov-Smirnov Test } \\
\hline Data & $\begin{array}{c}\text { Taraf } \\
\text { Signifikansi ( } \alpha)\end{array}$ & $\begin{array}{c}\text { Kolmogoro } \\
\text { v-Smirnov Z }\end{array}$ & $\begin{array}{c}\text { Asymp. } \\
\text { Sig. 2 } \\
\text { Tailed }\end{array}$ & Keterangan \\
\hline Metode Tanya Jawab & 0,05 & 1,054 & 0,217 & Normal \\
\hline Minat Belajar & 0,05 & 1,299 & 0,068 & Normal \\
\hline
\end{tabular}

Berdasarkan tabel 8 di atas, dapat diketahui bahwa nilai signifikansi untuk data metode tanya jawab (variabel X) sebesar 0,217 dan nilai signifikansi untuk data minat belajar (variabel Y) sebesar 0,068. Karena nilai signifikansi metode Tanya jawab (variabel X) dan minat belajar (variabel Y) $>0,05$, maka data metode Tanya jawab dan data minat belajar terdistribusi normal.

\section{Uji Linieritas}

Uji linieritas digunakan untuk mengetahui linieritas data yaitu apakah data variable mempunyai hubungan yang linier secara signifikan atau tidak. Uji linieritas ini digunakan sebagai persyaratan dalam analisi korelasi pearson atau regresi linier.

Adapun hasil uji linieritas antara dua variebel metode tanya jawab (X) dan minat belajar (Y) dijelaskan dalam tabel berikut

Tabel 9 : Hasil Perhitungan Uji Linieritas

\begin{tabular}{lccc}
\hline \multicolumn{1}{c}{ Data } & $\begin{array}{c}\text { Taraf Signifikansi } \\
(\boldsymbol{\alpha})\end{array}$ & Linearity & $\begin{array}{c}\text { Devation for } \\
\text { Linearity }\end{array}$ \\
\hline $\begin{array}{l}\text { Metode Tanya Jawab } * \\
\text { Minat Belajar }\end{array}$ & 0,05 & 0,000 & 0,907 \\
\hline
\end{tabular}

Berdasarkan tabel 9 di atas, maka dapat diketahui bahwa signifikansi Linearity sebesar 0,000. Karena signifikansi $0,000<0,05$ maka dapat dinyatakan bahwa antara variable $\mathrm{X}$ (Metode Tanya Jawab( danvariabel Y (Minat Belajar) terdapat hubungan yang linier.
Jika dilihat dari signifikansi pada Devation for Linearity, maka dapat dinyatakan bahwa ada hubungan yang linier antara variable X (Metode Tanya Jawab) dengan variable Y (Minat Belajar). Hal ini karena nilai signifikansi 0,907>0,05. 
Dari uji asumsi di atas, maka dapat diketahui bahwa data kedua variabel berdistribusi normal dan memiliki hubungan yang linier antara kedua variabelnya, maka penelitian ini menggunakan statistik parametrik yang merupakan bagian dari statistik inferensial yaitu statistik yang digunakan untuk menganalisi data sampel dan hasilnya diberlakukan untuk populasi. Dan untuk menjawab hipotesis penelitian yang menggunakan statistik parametrik dilakukan dengan teknik analisis korelasi pearson product moment, yang mana teknik analisis ini mensyaratkan data harus berdistribusi normal dan linier.

Hubungan Metode Tanya Jawab Dengan Minat Belajar Peserta Didik
Pada Mata Pelajaran Pendidikan Agama Islam Kelas VIII Di SMP Negeri 3 Simpang Raya Kecamatan Singingi Hilir Kabupaten Kuansing

Angket yang telah diperoleh kemudian diolah, dianalisis, dan disimpulkan menggunakan teknik analisis Korelasi Pearson. Teknik analisis Korelasi Pearson ini digunakan untuk menganalisis data tentang keeratan hubungan antara metode tanya jawab dengan minat belajar peserta didik pada mata pelajaran pendidikan agama Islam kelas VIII Di SMP Negeri 3 Simpang Raya Kecamatan Singingi Hilir Kabupaten Kuansing. Adapun hasil yang diperoleh dari SPSS 20 adalah sebagai berikut :

Tabel 10 : Hasil Analisis Korelasi Pearson antara Variabel Metode Tanya Jawab (X) dengan Variabel Minat Belajar (Variabel Y) Metode Tanya Jawab Minat Belajar

\begin{tabular}{rlrr}
\hline & Pearson & 1 & $.738^{* *}$ \\
\multirow{3}{*}{ Metode Tanya Jawab } & Correlation & & .000 \\
& Sig. (2-tailed) & 59 & 59 \\
& $\mathrm{~N}$ & & 1 \\
\multirow{3}{*}{ Minat Belajar } & Pearson & $.738^{* *}$ & \\
& Correlation & .000 & 59 \\
& Sig. (2-tailed) & 59 & \\
\hline
\end{tabular}

**. Correlation is significant at the 0.01 level (2-tailed).

Tabel 10 di atas menyajikan hasil koefisien korelasi Pearson Product Momentantara dua variabel yaitu variabel metode tanya jawab $(\mathrm{X})$ dan variabel minat belajar $(\mathrm{Y})$. Berdasarkan tabel tersebut diperoleh nilai probabilitas Sig.(2-tailed) lebih kecil dari 0,05 yaitu $0,000<0,05$, maka Ho ditolak. Artinya ada hubungan yang signifikansi antara metode tanya jawab dengan minat belajar peserta didik . Hasil korelasi ini sekaligus menjawab hipotesis penelitian dan membuktikan secara empiris bahwa ada hubungan metode tanya jawab dengan minat belajar peserta didik di SMP Negeri 3 Kuansing.

Kemudian untuk melihat seberapa besar hubungan antara variable metode tanya jawab (X) dengan variabel minat belajar $(\mathrm{Y})$ dapat dilihat dari nilai pearson correlation yaitu sebesar 0,738. Jadi hubungan antara metode tanya jawab dengan minat belajar peserta didik di SMP Negeri 3 Kuansing sebesar 0,738. Selanjutnya untuk melihat tingkat hubungan tersebut dapat dilihat pada 
tabel interpretasi koefisien korelatif

berikut

Tabel 11 : Interpretasi Koefisien Korelatif Metode Tanya Jawab dan Minat Belajar Peserta Didik di SMP Negeri 3 Kuansing

\begin{tabular}{cc}
\hline Interval Koefisien & Tingkat Hubungan \\
\hline $0,80-1,000$ & Sangat Kuat \\
$0,60-0,799$ & Kuat \\
$0,40-0,599$ & Cukup Kuat \\
$0,20-0,399$ & Rendah \\
$0,00-0,199$ & Sangat Rendah
\end{tabular}

Nilai $\quad 0,738$ pada interval koefisienkorelasi terletak direntang 0,60 - 0,799 dengan kriteria tingkat hubungan rendah. Ini artinya tingkat hubungan antara metode tanya jawab dengan minat belajar peserta didik di SMP Negeri 3 Kuansing adalah kuat.

\section{Interpretasi Data}

Berdasarkan hasil uji asumsi dinyatakan bahwa data metode Tanya jawab dan minat belajar terdistribusi dengan normal dan memiliki hubungan yang linier. Maka untuk menganalisis data penelitian digunakan statistic parametric dengan teknik analisis korelasi pearson product moment untuk melihat hubungan metode Tanya jawab dengan minat belajar peserta didik kelas VIII di SMP Negeri 3 Simpang Raya Kecamatan Singingi Hilir Kabupaten Kuansing.

Dari hasil analisis korelasi pearson product moment diperoleh nilai signifikansi lebih kecil dari 0,05 yaitu $0,000<0,05$, maka hipotesis penelitian diterima. Artinya ada hubungan yang signifikan antara metode Tanya jawab dengan minat belajar peserta didik kelas VIII di SMP Negeri 3 Simpang Raya Kecamatan Singingi Hilir Kabupaten Kuansing.
Besarnya tingkat hubungan metode Tanya jawab dengan minat belajar peserta didik tersebut dapat dilihat dari nilai probabilitaspearson correlation yaitu 0,738, ini artinya terdapat hubungan yang kuat antara metode Tanya jawab dengan minat belajar peserta didik kelas VIII di SMP Negeri 3 Simpang Raya Kecamatan Singingi Hilir Kabupaten Kuansing.

Hasil penelitian ini menunjukkan bahwa hubungan metode Tanya jawab dengan minat belajar peserta didik sangat penting bagi peserta didik agar memiliki pengetahuan yang lebih luas tentang pendidikan.

\section{SIMPULAN}

Berdasarkan hasil penelitian dan analisis data tentang hubungan metode Tanya jawab dengan minat belajar peserta didik kelas VIII di SMP Negeri 3 Simpang Raya Kecamatan Singingi Hilir Kabupaten Kuansing maka dapat disimpulkan bahwa: Terdapat hubungan signifikan metode tanya jawab dengan minat belajar peserta didik kelas VIII di SMP Negeri 3 Simpang Raya Kecamatan Singingi Hilir Kabupaten Kuansing dengan nilai hasil probabilitas Sig.(2-tailed) lebih kecil 
dari 0,05 yaitu $0,000<0,05$, maka Ho ditolak.

Tingkat hubungan metode tanya jawab dengan minat belajar peserta didik kelas VIII di SMP Negeri 3 Simpang Raya Kecamatan Singingi Hilir Kabupaten Kuansing sebesar 0,738. Menurut interpretasi koefisien korelasi nilai 0,738 terletak pada interval 0,60 0,799 dengan kriteria tingkat hubungan kuat.

Dari hasil penelitian yang telah penulis paparkan di atas, maka penulis mempunyai saran agar guru dalam proses pembelajaran menggunakan metode Tanya jawab agar tujuan pembelajaran dapat tercapai, karena metode Tanya jawab hubungannya sangat kuat dengan minat belajar peserta didik, peserta didik akan lebih aktif dalam pembelajaran. Karena tercapainya suatu pembelajaran itu tidak lepas dari metode pembelajaran.

\section{DAFTAR RUJUKAN}

Dairi, Rizal. 2014. Metodologi penelitian. Pekanbaru: UIR press.

DEPAG RI. 2009. Al-Qur'an dan terjemahannya. Bandung: Syigma Examedia Arkanleema.

Dimyati dan Mudjiono. 2013. Belajar dan pembelajaran. Jakarta: Rineka cipta.

Djaali. 2009. Psikologi pendidikan. Jakarta: Bumi aksara.

Ibrahim dan Syaodih, Nana. 2003. Perencanaan Pengajaran. Jakarta: Rineka Cipta.

Priyatno, Duwi. 2014. Pengolah data terpraktis. Yogyakarta: Andi Yogyakarta.

Rahmah. 2013. Psikologi umum. Pekanbaru.

Ramayulis. 2013. Profesi \& etika keguruan. Jakarta: Kalam mulia.
Riduwan dan Akdon. 2010. Rumus dan data dalam analisis statistika. Bandung: Alfabeta.

Riduwan dan Sunarto. 2011. Pengantar Statistika untuk penelitian pendidikan, sosial, ekonomi, komunikasi, dan bisnis. Bandung: Alfabeta.

Sanjaya, Wina. 2010. Strategi pembelajaran berorientasi standar proses pendidikan. Jakarta: Kencana.

Slameto. 2010. Belajar dan faktor-faktor yang mempengaruhinya. Jakarta: Rineka Cipta.

Soetomo. 1993. Dasar-dasar interaksi belajar mengajar. Surabaya: Usaha Nasional.

Sudjana, Nana. 2002. Dasar-dasar proses belajar mengajar. Bandung : Sinar Baru Algensindo.

Sugiono. 2012. Metode penelitian pendidikan. Bandung:ALFABETA.

Suhartono, Suparlan. 2009. Filsafat pendidikan. Yogyakarta: Ar-ruzz Media.

Suprijono, Agus. 2010. Cooperatif Learrning Teori \& Aplikasi Paikem. Yogyakarta: Pustaka belajar.

Tambak, Syahraini. 2014. 6 metode komunikatif PAI. Jakarta.

Tim Dosen. Pedoman Akademik Fakultas Agama Islam Universitas Islam Riau, Nomor 013, Tahun 2010, FAI UIR.

Trianto. 2010. Mendesain model pembelajaran inovatif-progresif. Jakarta: Kencana prenada media group.

Wiyani, Novan Ardy dan Barnawi. 2012. Ilmu pendidika islam. Yogyakarta: Ar-ruzz media.

\section{Skripsi}

Dewi Riana Sari dengan judul : Pengaruh Metode Tanya Jawab terhadap Kecerdasan Emosional Siswa pada Pelajaran PAI kelas VIII di SMPN 3 Desa Pasir Emas, 
Kecamatan Singingi Hilir,

Kabupaten Kuansing, 2014.

Putri Angraini dengan judul :
Studi Arab Melayu di SMPN 3

Pekanbaru, 2014.

Minat Belajar Siswa pada Bidang 